\title{
Gubernator tobolski Aleksander Despot-Zenowicz w świetle donosów*
}

Słowa klucze: Aleksander Despot-Zenowicz, gubernia tobolska, donosy, Syberia, XIX wiek

Keywords: Aleksander Despot-Zenowicz, Tobolsk Governorate, denunciations, Siberia, nineteenth century

Aleksander Despot-Zenowicz, gubernator tobolski w latach 1863-1867, zapisał się niezwykle korzystnie w pamięci nie tylko polskich zesłańców postyczniowych, lecz także rdzennych mieszkańców Tobolska i guberni tobolskiej. Poświęcono mu wprawdzie wiele tekstów, jednak liczne epizody jego życia i działalności nadal pozostają niewyjaśnione. Niewiele wiemy przede wszystkim o jego losach po odwołaniu ze stanowiska gubernatora tobolskiego.

Despot-Zenowicz rodził się w 1829 r. w Kietowiszkach w powiecie trockim województwa wileńskiego (gub. wileńska), jako najstarszy z czterech synów Jana. Jeden z jego braci, Stanisław (1835-1900), w latach 1879-1895 był naczelnikiem miasta Baku. Po ukończeniu szkoły średniej w Wilnie za jego dalszą edukację odpowiedzialność wzięła siostra cioteczna matki Aleksandra, Jelizawieta Iwanowna z domu Wierigina (1805-1875), żona późniejszego (od 1859 r.) generał-gubernatora moskiewskiego Pawła A. Tuczkowa (1803-1863). Dzięki niej wyjechał w 1845 r. do Moskwy i studiował prawo w tamtejszym uniwersytecie, który ukończył w 1848 r. W tym samym roku został jednak aresztowany i w trybie administracyjnym wydalony z miasta, po czym zamieszkał najpierw w Permie, a następnie w Tiumeni. Powszechnie uważa się, że powody tego swego rodzaju zesłania były polityczne. Zygmunt Librowicz ${ }^{1}$, który rozmawiał z Zenowiczem na ten temat, przekazał, że Zenowicz pytany o kulisy zawsze szybko ucinał rozmowę. Librowicz skłaniał się przy tym do wersji, że cała sprawa miała charakter raczej obyczajowy niż polityczny ${ }^{2}$.

* Tekst został przygotowany w ramach realizacji projektu NPRH „Polscy zesłańcy na Syberii Zachodniej w drugiej połowie XVIII wieku-XIX wieku w oczach Rosjan i ludności syberyjskiej”. Umowa nr 0098/NPRH3/H12/82/2014. Projekt realizowany przez UJK w latach 2014-2019.

${ }^{1}$ NOWIŃSKI (dostęp: 11 IX 2018).

${ }^{2}$ RGALI, ф. 442 оп. 1, д. 208, л. 17-18. Artykuł Librowicza zatytułowany jest: Десnот-Зенович - русский губернатор покровитель поляков. Очерк из недалекого прошлого Сибири. 
Wspomniany Paweł Tuczkow protegował Despot-Zenowicza generał-gubernatorowi Syberii Wschodniej, hrabiemu Nikołajowi N. Murawjowowi (Amurskiemu), który uchodził za liberała i starał się podjąć działania na rzecz rozwoju powierzonego mu w zarząd regionu. Jako podopieczny Tuczkowa trafił do Irkucka i objął stanowisko urzędnika do specjalnych poruczeń w Zarządzie Głównym Wschodniej Syberii (Главногое управление Восточной Сибири), а w 1852 r. został „komisarzem pogranicznym do spraw chińskich" w mieście Kiachta - bardzo ważnym punkcie rosyjsko-chińskiej wymiany handlowej. Mieszkańcy ośrodka z uznaniem oceniali działania nowego zarządcy, widząc $\mathrm{w}$ nim pioniera cywilizacji, organizatora życia kulturalnego i towarzyskiego. Swą działalnością sprzyjał on rozwojowi handlu, zakładaniu szkół i szerzeniu oświaty, propagował nowoczesne metody uprawy roli, hodowli itp. Był inicjatorem założenia biblioteki publicznej oraz klubu-czytelni, do których sprowadzał książki, a także gazety rosyjskie i zachodnioeuropejskie ${ }^{3}$. Za zasługi dla rozwoju miasta, a przede wszystkim za sukcesy w walce $\mathrm{z}$ korupcją i nadużyciami w 1859 r. otrzymał awans na naczelnika miasta (градоначальник) і pogranicznego gubernatora ze znacznymi pełnomocnictwami oraz jednorazową nagrodę pieniężną i dożywotnią pensję. Prowadził ważne gospodarczo-polityczne rozmowy z władzami chińskimi, a w 1861 r. zawarł konwencję handlową z Chinami, przyczyniając się znacząco do uregulowania zasad rosyjsko-chińskiego handlu lądowego ${ }^{4}$.

Jego działalność w Kiachcie zaczęła przynosić skarbowi poważne dochody, oceniane na $1,5 \mathrm{mln}$ rubli rocznie. Za te zasługi Zenowicz został odznaczony Orderem św. Włodzimierza III kl. oraz mianowany rzeczywistym radcą stanu. Otrzymał również dożywotnią pensję w wysokości tysiąca rubli, niezależną od innych świadczeń. Po likwidacji urzędu naczelnika Kiachty jesienią 1862 r. otrzymał nominację na gubernatora tobolskiego. Wybrał go osobiście Aleksander II z przedstawionych mu przez ministra Piotra Wałujewa trzech kandydatur.

W Tobolsku panowały wtedy nieporządki, z których car miał dobrze zdawać sobie sprawę, do legendy przeszły więc kulisy tej nominacji. Cesarz, powierzając Zenowiczowi w uznaniu jego energii i prawości zarząd prowincji, miał usłyszeć od nowego gubernatora: „Polakiem jestem, Najjaśniejszy Panie”, na co Aleksander II miał odpowiedzieć: „Jedź! ja tobie ufam, jedź i zaprowadź tam porządek”. Jakiż to porządek miał zaprowadzić Zenowicz? Przeżarta korupcją i nepotyzmem administracja guberni tobolskiej nie wyróżniała się pod tym względem na tle wielu innych rosyjskich guberni. Powodem zmiany gubernatora i licznych urzędników było urządzenie przez mieszkańców Tobolska entuzjastycznego przyjęcia zesłanemu na Syberię poecie Michaiłowi I. Michajłowowi. Wielu urzędników spotykało się z nim osobiście, a nawet podejmowało w swoich domach, przy czym gubernator Winogra-

\footnotetext{
SZEWCOW 2016, s. 9.

${ }^{4}$ NOWIŃSKI (dostęp: 11 IX 2018).

S. A. 1893 , s. 6.
} 


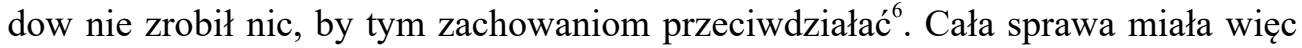
charakter polityczny, a mianowanie w tej sytuacji gubernatorem Zenowicza jeszcze bardziej przekonuje, jakim cieszył się zaufaniem. Nie było zresztą powodów, aby mu nie ufać, tym bardziej że — jeżeli rację miał Librowicz — Zenowicz nigdy nie uczynił niczego politycznie podejrzanego, a nadto został wcześniej przedstawiony osobiście Aleksandrowi II.

W innych okolicznościach sprawowanie funkcji gubernatora tobolskiego nie byłoby dla Zenowicza trudnym wyzwaniem. Mimo młodego wieku (nominowany miał 33 lata) miał wieloletnie doświadczenie w administracji i znał Syberię. Jednakże w 1862 r., kiedy w Królestwie i guberniach zachodnich było niespokojnie, taka nominacja dla Polaka i katolika musiała budzić wątpliwości, zwłaszcza że Zenowicz zawsze podkreślał swą narodowość i wyznanie. Tym bardziej że jeszcze przed przybyciem Zenowicza do Tobolska dotarło wielu Polaków zesłanych za udział w patriotycznych manifestacjach, po wybuchu powstania strumyk zesłańców przerodził się zaś w prawdziwą rzekę. Tobolsk na zesłańczym szlaku był bardzo ważnym punktem. Przez tamtejszą Ekspedycję ds. Zesłańców przeszli praktycznie wszyscy z nich, a co więcej często właśnie w Tobolsku przesądzał się ich dalszy los?

Nic więc dziwnego, że pierwszy swego rodzaju donos na Zenowicza napisano jeszcze zanim przybył do Tobolska. W liście jednego z tobolskich urzędników do kolegi w Warszawie czytamy: „Syberia nasza po brzegi zapełniona Polakami, którzy znaleźli tu sobie jakby Indie, a na koniec mianowali tobolskim gubernatorem Despot-Zenowicza, który sam przez dwa lata przebywał na zesłaniu w Permie, co z pewnością nie zostało zgłoszone cesarzowi. Będzie nam dobrze z tym wspaniałym polskim elementem!"․ W sytuacji powszechnej kontroli korespondencji donosem mógł stać się, wbrew intencjom autora, praktycznie każdy list. $Z$ całego listu żandarmi wynotowali właśnie przytoczony fragment.

Przybywszy do Tobolska, nowy gubernator przeprowadził szereg zmian personalnych $\mathrm{w}$ administracji guberni. Chociaż $\mathrm{w}$ tym względzie Zenowicz nie był wyjątkiem, wiele wątpliwości wywoływał styl wprowadzania tych zmian. Michaił Znamienskij przytacza rozmowę, którą odbył ze swoim przyjacielem Siemionem Kapustinem w Omsku. Gdy Znamienskij zachęcał go do przyjazdu do Tobolska w poszukiwaniu służby, ten odparł, że nie należy szukać tam służby przy gubernatorze, którego określił mianem idioty. Gdy Znamienskij zaoponował, Kapustin zaczął przekonywać, że tylko idiota może tak szybko oceniać ludzi wcześniej mu w ogóle nieznanych. „Trzeba w ogóle nie mieć zdrowego rozsądku, aby wszystko zmieniać” — uważał. „Kogo posadzi na ich miejsce? [...] Diugamel nic nie robi... i dobrze robi. Mniej złego może uczynić"”.

\footnotetext{
${ }^{6}$ GARF, ф. 109 , оп. 41, д. 7, ч. 5, л. 3-6.

${ }^{7}$ RGALI, ф. 442 оп. 1, д. 208, л. 5.

${ }^{8}$ GARF, ф. 109, оп. 38, д. 136, л. 3.

${ }^{9}$ ZNAMIENSKIJ 2013, s. 473.
} 
Wiele decyzji personalnych Despot-Zenowicza mogło budzić polityczne wątpliwości. Sprowadził on np. do Tobolska zesłanego do Bieriezowa, a więc ,politycznie podejrzanego" nauczyciela gimnazjum w Permie i urzędnika tamtejszego rządu gubernialnego Aleksandra Ikonnikowa, który domagał się rozbudowy szkół na Syberii i zorganizowania tam przynajmniej dwóch uniwersytetów ${ }^{10}$. Widocznie jednak nowy gubernator tobolski nie tylko nie bał się takich decyzji personalnych, lecz także potrafił je zrealizować.

Zdziwienie budziły też pierwsze decyzje gubernatora. Gdy bezpośrednio po przybyciu wydał zarządzenia dotyczące sprzątania miasta i naprawy mostów, po Tobolsku natychmiast rozeszły się plotki, że miasto ma odwiedzić następca tronu ${ }^{11}$. Przypadek ten znakomicie ilustruje sposób myślenia nie tylko urzędników, lecz także mieszkańców miasta. Po co bowiem naprawiać domy i mosty, jeżeli nie obejrzy ich jakiś zwierzchnik gubernatora? Dla samej wygody mieszkańców? Takie działanie widocznie musiano uważać za absurdalne.

Jednocześnie już pierwszymi zarządzeniami Despot-Zenowicz zyskał sobie przychylność licznych mieszkańców guberni. Wiosną 1863 r. nakazał wydać głodującym chłopom z powiatu bieriezowskiego zboże z państwowych magazynów. Zarządzenie wydawało się być oczywiste, ale problem polegał na tym, że formalnie zboże było przeznaczone do zaspokojenia potrzeb ,inorodców”, czyli ludów syberyjskich, głodujący byli zaś Rosjanami. Zenowicz złamał tym samym obowiązujące prawo ${ }^{12}$.

Działalność Zenowicza na stanowisku gubernatora tobolskiego szybko znalazła krytyków, a było ich niemało. Według Znamienskiego już po dwóch miesiącach pobytu Despot-Zenowicz wszedł w poważny spór z tobolskim biskupem prawosławnym ${ }^{13}$. Działalność gubernatora miała skutkować masą donosów na jego osobę i poczynania. Wiele informacji na ten temat znaleźć możemy w jednym $\mathrm{z}$ nieopublikowanych tekstów Zygmunta Librowicza. Dysponując nieznanymi nam materiałami, stwierdzał on, że „, do Piotrogrodu ${ }^{14}$ jeden za drugim wysyłane były donosy, że Zenowicz współczuje zesłanym Polakom, że daje im różne ulgi, że prawdopodobnie stoi na czele spisku, którego celem jest oddzielenie Syberii od Rosji przy udziale polskich zesłańców, że przygotowuje polskie powstanie na Syberii i.t.p.”. Autorami tych oskarżeń mieli być zarówno żandarmi, jak i urzędnicy, których nadużycia nowy gubernator ukróci1 ${ }^{15}$.

${ }^{10}$ SZEWCOW 2016, s. 10.

11 ZNEMIENSKIJ 2013, s. 427.

${ }^{12}$ SZEWCOW 2016, s. 9.

${ }^{13}$ ZNAMIENSKIJ 2013, s. 454.

${ }^{14}$ Tekst powstał prawdopodobnie w 1914 r., bowiem słowo „Petersburg” w maszynopisie ręcznie poprawiono na „Piotrogród”. RGALI, ф. 442, оп. 1,д. 208, л. 2. Tu najprawdopodobniej błąd literowy zamiast: Piotrogród.

${ }^{15}$ RGALI, ф. 442, оп. 1, д. 208, л. 11. 
Być może rzeczywiście donosów tych było mnóstwo, jednakże liczba tych, do których udało się nam dotrzeć, nie jest wcale tak znaczna, a co godne osobnego podkreślenia, żaden dokument sporządzony przez żandarmerię nie zawiera oskarżeń skierowanych personalnie przeciwko Zenowiczowi.

Na tle kilku anonimów wśród donosów na tobolskiego gubernatora z pewnością wyróżniają się te zidentyfikowane jako pisma autorstwa Jewgienija Michajłowicza Romanowicza. Dwa z nich powstały jesienią $1863 \mathrm{r}$. i skierowane zostały do samego cara Aleksandra II i szefa żandarmów Wasilija Dołgorukowa. Trzeci, z 1866 r., zaadresowano do następcy Dołgorukowa - Piotra Szuwałowa.

Jewgienij Michajłowicz Romanowicz (ok. 1817-?) — szlachcic z guberni kałużskiej, po ukończeniu nauki w Moskiewskim Korpusie Kadetów rozpoczął służbę w charakterze adiutanta w Arakczejewskim Pułku Dragonów w stopniu chorążego (praporszczika). W maju $1840 \mathrm{r}$. wstąpił na służbę do wydziału aprowizacji, z którego w 1842 r. został przeniesiony do Sztabu Korpusu Żandarmów, a po okresie próbnym został w marcu tego samego roku zatrudniony w Korpusie Żandarmów na stanowisku starszego adiutanta. W lutym 1843 r. mianowano go adiutantem oficera sztabowego żandarmerii guberni kostromskiej, w kwietniu został natomiast przeniesiony na stanowisko starszego adiutanta przy Sztabie Oddzielnego Korpusu Syberyjskiego, a jednocześnie do Ryskiego Pułku Dragonów, z którego zwolniono go w $1844 \mathrm{r}$.

Zakończywszy karierę wojskową, Romanowicz wstąpił do służby cywilnej, obejmując różne stanowiska. Sprawował m.in. urząd horodniczego w Iszimie (1846), Tiumeni i Tarze oraz naczelnika okręgu w Minusińsku (1860-1863). Po zwolnieniu ze służby próbował swoich sił jako restaurator w Tomsku, w którym to celu nabył nawet dom. Przedsięwzięcie poniosło jednak fiasko, a zrujnowany Romanowicz przeniósł się do Omska, gdzie próbował objąć posadę urzędniczą. Stanowczo sprzeciwił się temu generał-gubernator Zachodniej Syberii A.O. Diugamel, wobec czego Romanowicz przeniósł się do Tobolska. Tu, po spotkaniu z gubernatorem Despot-Zenowiczem, otrzymał propozycję objęcia stanowiska nadzorcy szpitala miejskiego, na co się nie zgodził, gdyż uważał, że nie odpowiada ono jego kwalifikacjom i doświadczeniu. Zapewne owa osobista uraza była powodem donosów na tobolskiego gubernatora ${ }^{16}$.

W piśmie do Aleksandra II Romanowicz pisał, że Despot-Zenowicz przyjął go w Tobolsku początkowo łaskawie, obiecując znaleźć mu odpowiadające jego kompetencjom stanowisko, po czym zapytał go po francusku, czy jest Polakiem. Gdy Romanowicz odpowiedział, że jest Rosjaninem, Despot-Zenowicz miał zmienić się na twarzy, odrzucić jego rękę i chłodno się pożegnać, a po kilku dniach przysłać policjanta $\mathrm{z}$ informacją, że posady $\mathrm{w}$ Tobolsku nie dostanie. Aby nie sprawić wrażenia, że powodem donosu jest osobisty żal do naczelnika guberni, w tym samym piśmie Romanowicz zarzucił również Despot-Zenowiczowi, że otoczył się Polakami

${ }^{16}$ GARF, ф. 109, оп. 38, д. 136, л. 42-43. 
i podejrzanymi politycznie Rosjanami, a prześladuje innych, całkowicie oddanych władzom Rosjan. Niektórych z nich miał nawet osobiście pobić.

Drugim powodem, dla którego według Romanowicza należało się dokładnie przyjrzeć działalności gubernatora tobolskiego, był jego stosunek do polskich zesłańców. Donosiciel informował, że gubernator praktycznie codziennie wizytuje tobolskie więzienie, gdzie długo rozmawia z zesłańcami „w cztery oczy”, a ponadto troszczy się o los księży, zwłaszcza Justyna Mielechowicza, którego sam ściągnął do Tobolska z Omska ${ }^{17}$.

Trzecim wreszcie zarzutem było oskarżenie Despot-Zenowicza o nadużycia finansowe, których miał się dopuścić jeszcze podczas swojej działalności w Kiach$\mathrm{cie}^{18}$. Romanowicz pisał, że, zarabiając „zaledwie” cztery tysiące rubli rocznie, Despot-Zenowicz miał zamawiać meble w Petersburgu, a do stolicy wysłał szesnaście worków ze srebrem, klejnotami i różnymi cennymi rzeczami. To ostatnie oskarżenie mogłoby być dla Despot-Zenowicza groźne, gdyby zostało uznane za prawdopodobne. Skąd jednak Romanowicz mógł znać szczegóły działalności Zenowicza w Kiachcie, skoro nigdy tam nie przebywał? Zapewne jedynie powtarzał krążące plotki.

Te same zarzuty Romanowicz zawarł w napisanym trzynaście dni później piśmie skierowanym do szefa żandarmów Dołgorukowa. Oskarżył Zenowicza o protegowanie wielu podejrzanych politycznie osób zajmujących eksponowane stanowiska $\mathrm{w}$ administracji guberni tobolskiej, a także o zwolnienie z pracy zasłużonych, znanych ze swego patriotyzmu i oddania Rosji urzędników ${ }^{19}$.

Efekt tych donosów był praktycznie żaden. Nie wiadomo, czy pierwszy list dotarł w ogóle do Aleksandra II - najprawdopodobniej nie. Dołgorukow zwrócił się wprawdzie z pismem do zwierzchnika Despot-Zenowicza, generał-gubernatora Zachodniej Syberii Aleksandra Diugalema, prosząc o ustosunkowanie się do zawartych w liście Romanowicza zarzutów, ale w odpowiedzi Diugamel nie tylko bardzo pochwalił dotychczasową działalność gubernatora tobolskiego, lecz także bronił sprawujących funkcje urzędnicze Polaków. Przekonywał, że do ich pracy i postawy nie ma żadnych zastrzeżeń, a zwalnianie ich tylko ze względu na narodowość w sytuacji, gdy na Syberii bardzo brakuje kompetentnych urzędników — uznał za poważny błąd.

O wiele gorliwiej niż gubernatorem i wspomnianymi w jego donosach osobami, żandarmeria zajęła się samym Romanowiczem. Zaczęto zbierać informacje o nim samym i jego poczynaniach w ostatnich miesiącach. Zarówno opinie miejscowej żandarmerii, jak i Pawła Blumentala, adiutanta Diugamela, były dla Romanowicza niekorzystne. Przekonywano, że jego niechęć do Zenowicza ma charakter osobisty, ponieważ, mimo że gubernator tobolski — w przeciwieństwie do wielu innych osób

\footnotetext{
${ }^{17}$ Romanowicz zniekształcił nazwisko księdza, przedstawiając go jako „Michlewicza”.

${ }^{18}$ GARF, ф. 109, оп. 38, д. 136, л. 14-18 об.

${ }^{19}$ GARF, ф. 109 , оп. 38, д. 136 л. 9-13.
} 
- zaproponował Romanowiczowi stanowisko kierownika tobolskiego szpitala, ten uznał to za obrazę, gdyż jego ambicje mierzyły dużo wyżej. Dziwiło to o tyle, że Romanowicz był zrujnowany finansowo. Przyznawano, że jest on osobą dobrze wykształconą, kulturalna i obytą, ale jednocześnie kłótliwą, Blumental pisał natomiast, że „nie zawsze w sposób umiarkowany używa on sherry” 20 .

Nie widząc żadnych efektów swoich działan, Romanowicz przycichł, ale trzy lata później uderzył znowu. Tym razem napisał list do szefa żandarmów Szuwałowa, dołączając do niego kopię donosu, który wysłał trzy lata wcześniej na ręce Aleksandra II. Zapewniając po raz kolejny o swoim bezgranicznym patriotyzmie i trosce o dobro Rosji, wyrażał obawę, że jego list do cara mógł po prostu nie dotrzeć, bo jak inaczej wytłumaczyć brak reakcji władz, na jego - Romanowicza - ostrzeżenia. Skutkiem owego braku reakcji miało być zawiązanie szeroko rozgałęzionego spisku Polaków na Syberii, czego efektem stało się powstanie zabajkalskie. Zdaniem Romanowicza nie mogło być inaczej w sytuacji, gdy liczne ważne stanowiska w administracji zajmują Polacy. Największego szkodnika upatrywał po raz kolejny właśnie w Despot-Zenowiczu, dowodząc, że jego działania, dzięki którym uważany jest za jednego z lepszych gubernatorów w Imperium, nie mogą przesłonić faktu, że jest on Polakiem i zawsze sprawa polska będzie dla niego ważniejsza od interesu państwa rosyjskiego. Według Romanowicza pouczający miał być w tym względzie przykład Jozafata Ohryzki, uważanego skądinąd za znakomitego urzędnika. Zacytował on słowa Ohryzki, który w czasie swojego procesu powiedział, że „rodząc się Polakiem, nigdy nie przestawał nim być". Jak zaznaczył Romanowicz, te same słowa można było odnieść do Despot-Zenowicza, a w sytuacji, gdy polscy zesłańcy mieli tak wpływowego protektora i znaleźli sobie na Syberii nową „ziemię obiecaną", powstanie polskich legionów na Syberii jest tylko kwestią czasu ${ }^{21}$.

Reakcja władz na ów donos musiała tym razem zaskoczyć, zwłaszcza samego donosiciela. Na początku 1867 r. petersburski policmajster Fiodor Triepow wystąpił do ministra spraw wewnętrznych Piotra Wałujewa $z$ wnioskiem o wydanie Romanowiczowi zakazu zamieszkiwania $\mathrm{w}$ stolicach i stołecznych okręgach, zarzucając mu pijaństwo i brak określonego zajęcia. Wałujew przychylił się do wniosku, a nawet polecił wysłać Romanowicza do ,jednej z oddalonych guberni” i objąć go policyjnym nadzorem ${ }^{22}$.

Trzy pozostałe donosy - jak już wspomniano - były anonimami. Dwa z nich wysłano na adres Michaiła Murawjowa, który, mimo że nie sprawował już stanowiska generał-gubernatora wileńskiego, wciąż był tak tytułowany. Widocznie sądzono, że „Wieszatiel” Murawjow — wzór dla wszystkich rosyjskich „patriotów” — zareaguje na doniesienia z Syberii, a skoro wciąż pozostaje niezmiernie wpływowy i ustosunkowany, jego reakcja przyniesie pożądany skutek. Wzmianki o Zenowiczu

\footnotetext{
${ }^{20}$ GARF, ф. 109 , оп. 38, д. 136, л. 42-43.

${ }^{21}$ GARF, ф. 109, оп. 38, д. 136, л. 78-79 об.

${ }^{22}$ GARF, ф. 109, оп. 38, д. 136, л. 90.
} 
w tych donosach są krótkie. Wspomniano w nich jedynie, że tobolski gubernator jest protektorem polskich zesłańców i ich niecnych zamysłów i działań, nie podając przy tym żadnych konkretnych przykładów. Nie ma w tym nic dziwnego, skoro jeden $\mathrm{z}$ donosów pisany był z Irkucka, a autor drugiego też zapewne nie wiedział, co tak naprawdę dzieje się w Tobolsku, więcej pisząc o wydarzeniach w guberniach tomskiej i jenisejskiej. Interesującej treści obydwu donosów nie będziemy tu jednak szerzej omawiać, gdyż — jak wspomniano - wzmianki o tobolskim gubernatorze są w nich lakoniczne ${ }^{23}$. Autorów donosów żandarmeria nie ustaliła. Jeden z nich, obawiając się widocznie zdemaskowania, pisał wyłącznie wielkimi literami. Donos pochodzący z Irkucka miał być wyrazem zaniepokojenia całego rosyjskiego środowiska, nikt jednak nie podpisał się pod nim z imienia i nazwiska.

W jednostkach archiwalnych, w których znajdują się te donosy, brak śladów, by żandarmeria podjęła inne działania niż próba ustalenia autorstwa. Nie wiadomo również, czy w ogóle dotarły one do adresata czy też zostały przez żandarmów przechwycone na etapie kontroli korespondencji. Są one jednak pełne nazwisk i rozmaitych szczegółów, dlatego też trudno przypuszczać, że żandarmeria pozostawiła je bez żadnej reakcji.

Dużo więcej miejsca działalności Zenowicza poświęcił autor ostatniego $\mathrm{z}$ anonimów, napisanego najprawdopodobniej nie wcześniej niż w maju 1866 r., a wysłanego na adres szefa żandarmów Dołgorukowa. Autor pochodził najprawdopodobniej z Tobolska, bo list pełen jest istotnych szczegółów, a działalności tobolskiego gubernatora autor, podpisany jako prirodnoj russkij, poświęcił ponad połowę tekstu. Stwierdzał w nim, że w Rosji źle się dzieje, nie może jednak być inaczej w sytuacji, gdy rządzą w niej tacy jej wrogowie jak Despot-Zenowicz — ,jezuita z natury, zatwardziały Polak, krwi rosyjskiej żądny". To właśnie Zenowicz miał stać na czele polskiego spisku na Syberii, rozsyłając po kraju swoich agentów, nie tylko zresztą Polaków, lecz także związanych z nim Rosjan. Jego działania jako administratora nie były zaś niczym innym, jak próbą przeciągnięcia na stronę spiskowców miejscowej ludności, w tym również rdzennych ludów syberyjskich.

Kolejnym zarzutem wobec tobolskiego gubernatora było oskarżenie go o protegowanie księży, ostentacyjne obnoszenie się ze swym katolicyzmem i działanie na szkodę prawosławia. „Jak można — pisał autor donosu — trzymać gubernatora-Polaka w Tobolsku, gdzie zwożą przestępców politycznych z całej Rosji”. Co gorsza, Zenowicz ściągnął do Tobolska całą gromadę urzędników polskiego pochodzenia, za pośrednictwem których realizuje swoje spiskowe plany. Autor donosu sugerował, że trzeba natychmiast zastąpić „zatwardziałego Polaka” twardym wojskowym czysto rosyjskiego pochodzenia, w przeciwnym razie w ciągu kilku miesięcy na całej Zachodniej Syberii wybuchnie powstanie, które przyjdzie thumić wielkim nakładem sił i środków ${ }^{24}$.

\footnotetext{
${ }^{23}$ GARF, ф. 109, оп. 2 а, д. 705, л. 9-11; ф. 109, оп. 41, д. 38, ч. 3, л. 60-61.

${ }^{24}$ Treść całego donosu: GARF, ф. 109, оп. 38, д. 136, л. 48-56.
} 
Akta zachodniosyberyjskiej żandarmerii z tego okresu zachowały się niestety szczątkowo. Pełne odtworzenie reakcji władz na skargi na działalność i osobę gubernatora tobolskiego nie jest więc możliwe. Nie wiemy, czy i na ile miejscowa żandarmeria zajęła się sprawdzeniem przedstawionych $\mathrm{w}$ donosach zarzutów. $\mathrm{Z}$ zachowanego materiału wynika, że żandarmeria starała się — w przypadku anonimów — w pierwszym rzędzie ustalić tożsamość autora donosu, a dopiero później ewentualnie prawdziwość zawartych w nim informacji ${ }^{25}$.

Czy i na ile donosy zaszkodzily Aleksandrowi Despot-Zenowiczowi i jego urzędniczej karierze? Przynajmniej te donosy, do których udało nam się dotrzeć, na pewno nie szkodziły mu bezpośrednio, gdy — jak już wspomniano — donosy Romanowicza obróciły się przeciw niemu samemu.

We wspomnianym tekście Librowicza znajduje się informacja, że z powodu donosów wezwano Zenowicza do Petersburga w celu złożenia wyjaśnień. Niestety Librowicz nie podaje, kiedy miało się to zdarzyćc ${ }^{26}$.

$\mathrm{Na}$ zarzuty o związki z polskimi zesłańcami gubernator tobolski odpowiedział, że stara się jedynie humanitarnie do nich podchodzić, ulżyć ich doli, zachować porządek w więzieniu i tępić nadużycia, ale ani na jotę nie odstąpił nigdy od przepisów i nie naruszył prawa. Na zarzut, że prowadzi własną politykę, Despot-Zenowicz odpowiedział zaś w notatce złożonej na ręce cara. Nie udało nam się dotrzeć do oryginału tego dokumentu, dysponujemy jedynie zacytowanymi przez Librowicza jej fragmentami. Gubernator tobolski pisał:

Gubernator jest organem wykonawczym centralnej władzy. Nie może więc prowadzić własnej polityki. Ale nie tylko w realizacji tych czy innych instrukcji, ale także w stosowaniu przepisów prawa gubernator nie powinien patrzeć na siebie jak na ślepe narzędzie w rękach zwierzchności. Może i powinien [...]. Wielkim nieszczęściem Rosji jest to, że posiadający władzę starają się wywołać u ludności jedynie strach, pokazać swoją siłę, a nikt nie troszczy się o to aby wzbudzić jeżeli nie miłość, to przynajmniej szacunek dla władzy ${ }^{27}$.

Dalej Librowicz pisze, że Aleksander II nie tylko nie zdymisjonował Zenowicza, lecz także zgodził się z zawartymi w cytowanej notatce treściami i wyraził mu za jej napisanie „osobistą wdzięczność”. Po powrocie do Tobolska gubernator miał się rozprawić z osobami, które przekonane, że już nie wróci, zaczęły zmieniać wprowadzone przez niego porządki, prześladując m.in. polskich zesłańców; jego niezadowolenie dotknęło zapewne również osoby podejrzane o pisanie donosów ${ }^{28}$.

${ }^{25}$ GARF, ф. 109, оп. 38, д. 136, passim.

${ }^{26}$ RGALI, ф. 442, оп. 1, д. 208, л. 11-12. Być może ta podróż odbyła się w 1865 r. W niektórych tekstach poświęconych Zenowiczowi znaleźć można informację o jego wyjeździe do stolicy, co czasami błędnie wiązane jest z opuszczeniem przez niego stanowiska gubernatora tobolskiego (cf. WÓJCIK 2015, s. 131).

${ }^{27}$ RGALI, ф. 442, оп. 1, д. 208, л. 12.

${ }^{28}$ RGALI, ф. 442, оп. 1, д. 208, л. 12-13. 
W związku z tym niewyjaśnione pozostają kulisy dymisji Zenowicza ze stanowiska gubernatora, z którego został odwołany w czerwcu 1867 r., faktycznie sprawował więc ten urząd niewiele ponad cztery lata. Warto zauważyć, że jego poprzednik utrzymał się na stanowisku trzy i pół roku, a następca - niecały rok, natomiast na 34 tobolskich gubernatorów dłużej ów urząd sprawowało jedynie siedmiu ${ }^{29}$. Czasami możemy spotkać się z opiniami, że do odwołania go przyczyniły się właśnie płynące do Petersburga coraz liczniejsze skargi i donosy, ale - jak słusznie zauważa Franciszek Nowiński — żadne znane historykom dokumenty tego nie potwierdzają ${ }^{30}$. Nam również podczas licznych kwerend $\mathrm{w}$ archiwach rosyjskich nie udało się na takie dokumenty natrafić. Jego odwołanie można by wiązać z również dymisją w listopadzie 1866 r. generał-gubernatora Aleksandra Diugamela, również katolika uważanego za liberała, oskarżanego o zbyt „miękkie” traktowanie polskich zesłańców, jednakże w ciągu pół roku od dymisji Despot-Zenowicza stanowiska stracili również gubernator tomski Gierman Lerche i gubernator jenisejski Paweł Zamiatnin, których o sympatię dla zesłańców i w ogóle Polaków posądzać nie można.

Wedle niektórych informacji to sam Despot-Zenowicz poprosił o dymisję, thumacząc to złym stanem zdrowia. Oczywiście mogła to być jedynie zasłona prawdziwej przyczyny, wszakże podobne prośby często pisali urzędnicy, których odwołanie było już przesądzone, co pozwalało im honorowo opuścić stanowisko. Posiadamy jednak informacje, że ze zdrowiem Despot-Zenowicza rzeczywiście nie było najlepiej — na początku 1867 r. przeszedł on najprawdopodobniej udar, po którym został częściowo sparaliżowany $^{31}$. Widocznie nie był on jednak zbyt rozległy, skoro Zenowicz przeżył jeszcze prawie trzydzieści lat i nic nie wiemy o tym, by stale niedomagał. Prawdopodobnie na decyzję gubernatora o napisaniu prośby o dymisję wpłynęły dwa czynniki: zdawał sobie sprawę, że jego odwołanie i tak jest tylko kwestią czasu, a dodatkowo organizm dawał mu znać, że należy odpocząć i zadbać o zdrowie.

Innego zdania był Gieorgij Potanin, autor artykułu o życiu i działalności Zenowicza opublikowanego w gazecie „Sibirskaja Żizń”. Opisał on dokonania gubernatora w bardzo ciepłych słowach. Wspomniał również, że na Zenowicza sypały się donosy — w opinii autora potwierdzały tylko prawość i energiczność jego działań. Jego zdaniem to właśnie w sprawach najlepszych administratorów wysyłano najwięcej tego rodzaju doniesień. Przekonywał też, że być może w innych warunkach donosy niczym by nie skutkowały, gdyby nie pochodzenie Zenowicza, które jako niemożliwy do ukrycia swego rodzaju defekt było skrzętnie wykorzystywane przez jego wrogów ${ }^{32}$.

${ }^{29}$ ru.wikipedia.org/wiki/\%D0\%A2\%D0\%BE\%D0\%B1\%D0\%BE\%D0\%BB\%D1\%8C $\% \mathrm{D} 1 \% 81 \%$ D0\%BA\%D0\%B0\%D1\%8F_\%D0\%B3\%D1\%83\%D0\%B1\%D0\%B5\%D1\%80\%D0\%BD\%D0\%B8\% D1\%8F (dostęp: 12 VIII 2018).

${ }^{30}$ NOWIŃSKI (dostęp: 11 IX 2018).

31 S.A. 1893 , s. 8.

32 „Sibirskaja żyzń” 1903, s. 2. 
Stanowisko gubernatora tobolskiego było szczytem urzędniczej kariery młodego przecież jeszcze Despot-Zenowicza. W chwili dymisji nie miał on nawet czterdziestu lat. Odwołany do Petersburga otrzymał wprawdzie „ciepłą” posadę w ministerstwie spraw wewnętrznych, jednakże już nigdy nie objął samodzielnego stanowiska. Na ile wpłynęły na to donosy - trudno rozstrzygnąć. Bez odpowiedzi pozostaje pytanie, czy Despot-Zenowicz w ogóle o stanowisko ministerialne zabiegał. Z pewnością jednak zaszkodziły mu brak protektorów (Murawjow-Amurski) i jego własna postawa. $\mathrm{W}$ dniu uniewinnienia Wiery Zasulicz przez sąd przysięgłych Zenowicz miał paradować w mundurze po Petersburgu i powtarzać, że jest to jeden z najszczęśliwszych dni w jego życiu. Możemy wprawdzie znaleźć wzmianki, że w okresie sprawowania urzędu ministra spraw wewnętrznych przez jego przyjaciela Michaiła Loris-Mielikowa rozpatrywana była jego kandydatura na jakieś eksponowane stanowiska, ale śmierć Aleksandra II przekreśliła te plany ${ }^{33}$.

Nigdzie nie udało nam się natrafić również na informację, że Zenowicz był załamany utratą gubernatorstwa ani że zabiegał później o jakieś stanowisko. Może więc niezwiązana z szerokim zakresem władzy, ale spokojna, dobrze płatna i niepołączona $\mathrm{z}$ jakąś szczególną odpowiedzialnością praca $\mathrm{w}$ ministerstwie spraw wewnętrznych po prostu mu odpowiadała, a po wielu latach spędzonych na Syberii wolał stateczne życie w stolicy? Powróćmy do sygnalizowanej już kwestii: na ile donosy mogły przyczynić się do dymisji ze stanowiska tak wysokiego urzędnika? Oczywiście należałoby tu rozpatrzyć cały szereg indywidualnych przypadków, można jednak zaryzykować stwierdzenie, że nie szkodzily one do czasu, gdy zarzutów pojawiających się w donosach nie potwierdziły instytucje urzędowe, a przede wszystkim żandarmeria. W końcu gubernatora mianował sam car, więc jego usunięcie ze stanowiska z powodu donosu byłoby w pewnym sensie również podważeniem autorytetu władzy.

$Z$ drugiej jednak strony oskarżeń w donosach nie ignorowano całkowicie. Gdy któryś z urzędników popadł z różnych powodów w niełaskę - co często było efektem walk frakcyjnych w kręgach zarówno petersburskich, jak i prowincjonalnych elit - chętnie wyciągano zapomniane, zdawałoby się, donosy, czyniąc z nich argument uzasadniający dymisję urzędnika. Przykładem może być tu choćby sprawa kijowskiego generał-gubernatora Aleksandra Bezaka, w którego przypadku donosy okazały się początkowo bezskuteczne. Jeszcze na początku 1868 r. minister Wałujew skarżył cię carowi, że nie ma żadnej reakcji na niepokojące doniesienia z Kraju Południowo-Zachodniego, które powinny stać się przynajmniej powodem kontroli. Kiedy jednak w nie do końca wyjaśnionych okolicznościach Bezak stracił zaufanie cara, do zarzutów tych wrócono ${ }^{34}$. Być może zawarte w donosach na Zenowicza oskarżenia były chociaż częściowo słuszne? Jeżeli sami polscy zesłańcy uważali go za swego protektora i dobroczyńcę, to może rzeczywiście gubernator łamał prawo, aby ulżyć ich losowi? Zenowicz — jak sam miał wspomnieć w notatce skierowa-

\footnotetext{
${ }^{33}$ NOWIŃSKI (dostęp: 11 IX 2018).

${ }^{34}$ Więcej na ten temat: LEGIEĆ, LATAWIEC 2018, s. 50-52.
} 
nej do cara — nigdy przepisów nie złamał. Co najwyżej je naginał i interpretował w sposób korzystny dla zesłanych. Sytuacja zesłańców, którzy znaleźli się w guberni tobolskiej, była rzeczywiście zdecydowanie lepsza niż tych, którzy trafili do innych guberni, co nie było jednak wyłączną zasługą gubernatora.

Zasługi Zenowicza na tym polu można ocenić jako wyjątkowe. Gubernator wielokrotnie podkreślał, że zesłańcom należy przede wszystkim znaleźć zajęcie, dzięki któremu nie tylko będą mogli zarobić na swoje utrzymanie, lecz także znajdą cel w życiu. Bieda, brak zajęcia i nadziei na poprawę swojego losu miały pchać ludzi do desperackich kroków, w tym spiskowania i prób wzniecenia zbrojnego buntu. W guberni tobolskiej odnotowano tylko jedną ucieczkę zesłanego, podczas gdy w innych guberniach przypadków takich było znacznie więcej ${ }^{35}$. Dzięki temu, że zesłańcy sami zarabiali na swoje utrzymanie, zmniejszało się też obciążenie skarbu z tego tytułu.

Należy jednak podkreślić, że sprawy zesłańców nie były ani jedynym, ani nawet najważniejszym polem administracyjnej aktywności Zenowicza. Po analizie wydanych drukiem okólników gubernatora tobolskiego z lat 1863-1867 można przekonać się, że niewiele ponad $10 \% \mathrm{z}$ nich dotyczy zagadnień związanych z tym tematem ${ }^{36}$. Oczywiście nie można wykluczyć, że część z okólników miała charakter tajny, ale, czytając zarządzenia gubernatora możemy przekonać się, jak wiele uwagi poświęcił on sprawom gospodarczym i społecznym. Żadna z tych aktywności Zenowicza nie stała się przedmiotem donosu.

Czy więc gubernator był tak kryształową postacią, jak można wywnioskować, studiując relacje zesłańców i czytając większość tekstów na jego temat? Z pewnością nie. Wiele krytycznych słów poświęcił mu na łamach wydanego niedawno dziennika Michaił Znamienskij, znany syberyjski malarz i rysownik, który w tym czasie był nauczycielem w Tobolsku. Chociaż Despot-Zenowicz zamawiał u niego wiele rysunków i oficjalnie pozostawał z nim w dobrych relacjach, to Znamienskij wielokrotnie wspominał, że gubernator był osobą bardzo pewną siebie, przekonaną o własnej nieomylności, lubiącą podkreślać swoje zasługi i dokonania, na które pracował często cały zespół ludzi. Ponadto zarzucał mu, że zbyt łatwo oceniał ludzi krytycznie na podstawie pierwszego wrażenia ${ }^{37}$.

Podobnego zdania musiał być syberyjski poeta i pisarz, a jednocześnie dyrektor tobolskiego gimnazjum w czasach rządów Despot-Zenowicza Piotr Pawłowicz Jerszow, który poświęcił gubernatorowi złośliwy epigram. Pisał on:

Тебя я умным признавал,

Ясновельможная особа,

А ты с глупцом меня сравнял...

Быть может, мы ошиблись оба! $!^{38}$

\footnotetext{
${ }^{35}$ RGALI, ф. 442, оп. 1, д. 208, л. 7.

${ }^{36}$ Sbornik 1867, passim.

${ }^{37}$ Jednakże w wielu miejscach Znamienskij, nawet jeżeli nie chwali Zenowicza wprost, to i tak nie szczędzi mu ciepłych słów.

38 JERSZOW 1950 (dostęp: 13 VIII 2018).
} 
O tych cechach charakteru Zenowicza mimochodem wspomina również Librowicz. Gubernator tobolski często lubił podkreślać, że jest potomkiem serbskich książąt, którzy w XV w. przybyli na Litwę, a także, że przydomek „Despot” był nie tyle członem nazwiska, ile tytułem równym książęcemu ${ }^{39}$ - dlatego też bardzo się irytował, gdy jego nazwisko pisano $\mathrm{z}$ dywizem.

Czy jednak jakikolwiek donosiciel mógł nawet pomyśleć, aby o tych cechach charakteru napisać w donosie? Granica między pewnością siebie a zarozumiałością jest przecież czasami bardzo cienka i płynna. Gubernator Despot-Zenowicz, jak każdy urzędnik tego szczebla, prowadził własną politykę kadrową. Czy można mu mieć za złe, że przywiózł ze sobą do Tobolska kilku zaufanych ludzi, z którymi pracował w Kiachcie? Etatów nie mógł mnożyć, więc miejsca dla nich musieli ustąpić inni. Usuwał ze stanowisk ludzi, których uważał za leniwych i niekompetentnych. Miał prawo do takich ocen, ale $\mathrm{z}$ drugiej strony osoby zwolnione $\mathrm{z}$ pracy bądź zdegradowane również miały prawo czuć się skrzywdzone. W takiej sytuacji donos jawił się jako naturalne narzędzie zemsty. Niemniej była to droga ryzykowna, donosiciel musiał być ostrożny, ponieważ oskarżał osobę ustosunkowaną, często mającą możnych protektorów. Gdyby zarzuty się nie potwierdziły, musiał liczyć się z karą. Ponadto nawet gdy osiągnął swój cel, a jego nazwisko stało się znane i tak ciągnęła się za nim opinia „stukacza”, która mogła zaważyć nie tylko na karierze, lecz także na stosunkach towarzyskich.

Jeszcze raz należy podkreślić, że nie znamy dokładnie kulisów dymisji Despot-Zenowicza ze stanowiska gubernatora tobolskiego, ale donosy na jego działalność, przynajmniej te, do których udało nam się dotrzeć, nie miały na nią najpewniej żadnego wpływu. Informacje od mało wpływowych osób, a zwłaszcza anonimy, nie mogły zaszkodzić tak wysokim urzędnikom jak gubernator, chyba że wpisywały się w walki frakcyjno-personalne na szczytach władzy, a informacjami w nich zawartymi zajęła się osoba o wpływach i pozycji co najmniej równej randze bohatera donosu. W przeciwnym razie zarówno donosiciel, jak i jego „dzieło” byli raczej przedmiotami niż sprawcami rozgrywek.

\section{WYKAZ CYTOWANYCH ŹRÓDEŁ I LITERATURY PRZEDMIOTU}

\section{ŹRÓDŁA RĘKOPIŚMIENNE I MATERIAŁY NIEPUBLIKOWANE}

GARF [= Государственный архив Российской Федерации], ф. 109, оп. 2 а, д. 705; оп. 41, д. 7 , ч. 5 , д. 38 , ч. 3 ; оп. 38 , д. 136

RGALI [= Российский государственный архив литературы и искусства], ф. 442, оп. 1, д. 208

\footnotetext{
${ }^{39}$ RGALI, ф. 442, оп. 1, д. 208, л. 16.
} 


\section{ŹRÓDŁA DRUKOWANE I LITERATURA PRZEDMIOTU}

JERSZOW 1950 = П.П. Ершов, А.И. Деспоту-Зеновичу, w: П.П. Ершов, Сочинения, Омск 1950, www.biblioteka-poeta.ru/a-i-despotu-zenovichu-tebya-ya-umnym-priznaval/ershov-p-p (dostęp: 13 VIII 2018)

LEGIEĆ, LATAWIEC 2018 = Jacek Legieć, Krzysztof Latawiec, Prawobrzeżna Ukraina. Czasy Annienkowa i Bezaka (1864-1868), Kielce 2018

NOWIŃSKI = Franciszek Nowiński, Despot-Bartoszyński-Zenowicz Aleksander, w: Polski Petersburg, http://www.polskipetersburg.pl/hasla/despot-batoszynski-zenowicz-aleksander (dostęp: 11 IX 2018)

S.A. 1893 = S.A., Despot Zenowicz b. gubernator tobolski, Lwów 1893

Sbornik 1867 = Сборник ичирклярных распоряжений начальника Тобольской губернии: (с 15 февраля 1863 г. по 27 января 1867 г.), [авт. предисл.: Тобольский губернатор Деспот Зенович], Тобольск 1867

Sbornik 2015 = Сибири во второй половине XVIII-начале XX века в восприятии российской администрации, переселенцев и коренных народов Сибири, Омск 2015

„Sibirskaja żyzń” 1903 = „Сибирская жизнь”, 1903, 169, XIV иллюстрированное приложение к газете

SZEWCOW 2016 = В.В. Шевцов, „Тобольские Губернские Ведомости” (1857-1867) в период губернаторства В. А. Ариимовича, А. В. Виноградского и А. И. ДеспотЗеновича, „Вестник Томского государственного университета”, 2016, История, 1 (39)

WÓJCIK 2015 = Zbigniew Wójcik, Aleksander Despota-Zenowicz w oczach zesłańców, w: Польские ссылъные в Сивири во второй половине XVIII - начале XX века в восприятии российской администрачии, переселенцев и коренных народов Сибири. Сборник научных трудов, редкол. С.А. Мулина и др., Омск 2015

ZNAMIENSKIJ 2013 = М.C. Знаменский, Воспоминания и дневник, Тобольск 2013 ru.wikipedia.org/wiki/\%D0\%A2\%D0\%BE\%D0\%B1\%D0\%BE\%D0\%BB\%D $\%$ D 8 C \% D 1\%81\%D0\%BA\%D0\%B0\%D1\%8F_\%D0\%B3\%D1\%83\%D0\%B 1\% D0\%B5\%D1\%80\%D0\%BD\%D0\%B8\%D1\%8F (dostęp: 12 VIII 2018)

\section{The Governor of Tobolsk Aleksander Despot-Zenowicz in the light of denunciations}

Aleksander Despot-Zenowicz, a Pole who in 1863-1867 served as the Governor of Tobolsk, was remembered by Poles exiled to Siberia after the January Uprising as their protector, a person thanks to whom it was possible to reduce the hardship of exile to some extent. The prevailing opinion in the literature on the subject is that this led to a huge number of denunciations sent to the governor's superiors, including Tsar Alexander II himself. DespotZenowicz was accused in them of favouring Poles or even of plotting to separate Siberia from Russia. Some believe that it was the denunciations that were the cause of his dismissal. In the article the author analyses the content of the surviving denunciations and assesses their impact on the governor's career. It turns out that the number of denunciations was not so high (obviously, some may not have survived) and their impact on the evaluation of DespotZenowicz's activity by his superiors was minimal. In some cases the denunciations were more detrimental to the informer than to the person informed against. 